\title{
PHYSIOLOGICAL ANALYSES OF AN OVER-EXPRESSING CYTOKININ METABOLIC GENE GmIPT10 UNDER NORMAL AND DROUGHT CONDITIONS
}

\author{
Nguyen Ngoc Hai, Nguyen Duc Van Thien, Hoang Thi Lan Xuan, Nguyen Phuong Thao \\ International University, Vietnam National University, Ho Chi Minh City
}

${ }^{\square}$ To whom correspondence should be addressed. E-mail: npthao@hcmiu.edu.vn

Received: 01.8.2017

Accepted: 20.11.2017

\section{SUMMARY}

Cytokinin (CK) is an important phytohormone, which not only plays significant role in plant development but also involves in mediating plant stress tolerance. Previous studies showed that the drought tolerance can be improved by stress-inducible overexpression of adenine isopentenyl transferase (IPT), which is a critical enzyme in CKs biosynthesis. To study the role of soybean GmIPT10 in regulating plant tolerance, we successfully generated GmIPT10-overexpressing transgenic soybean plants and screened a line carrying homozygous, single copy of transgene. Analyzing several physiological traits of this line demonstrated that it possessed stress tolerance characteristics, including increased primary root and shoot lengths, better production of shoot biomass, higher number of trifoliate leaves, and higher survival rate than the non-transgenic plants under drought condition. The net house experiments also showed that the GmIPT10-overexpressing transgenic soybean had a greater relative water content compared to the control genotype under applied drought condition. Therefore, this report indicated that plant drought tolerance might be enhanced via regulating expression of GmIPT10.

Keywords: Cytokinin, drought tolerance, GmIPT10, soybean, transgenic plant

\section{INTRODUCTION}

Soybean (Glycine max) is an important crop used commonly in producing vegetable oil, protein and nutrition feed. However, drought stress has been concerned as one of the most critical factors determining the final yield of soybean (Tran and Mochida, 2010). Previous studies have reported drought can reduce soybean production up to $40 \%$ (Thao and Tran, 2012). Making stable genetically modified soybean cultivars by genetic engineering has been considered as a productive and rapid method to improve drought-tolerant traits (Guttikonda et al., 2014). By utilizing in silico analysis-based approach, a large number of cytokinin (CK) - related genes involved in drought adaptation have been systematically characterized and functionally studied (Hwang, Sheen, 2001; Inoue et al., 2001). Regarding aspect of plant physiology, CK is well known as a regulator in morphological (Muller et al., 2008; Werner et al., 2010) and physiological development (Aloni et al., 2006) as well as in plant adaptation to environmental stresses, such as tolerant response to drought stress (Muller et al., 2007; Kuppu et al., 2013). Protective responses to drought in plants could be, therefore, modified by genetic engineering through manipulation of endogenous CK levels (Le et al., 2012).

In the past 20 years, a great deal of effort on research has been conducted to draw a detailed picture of $\mathrm{CK}$ metabolism. In plants, $\mathrm{CK}$ metabolic homeostatic is consistently regulated by adenosine phosphate-isopentenyl transferases (IPTs) and CK oxidases/dehydrogenases (CKXs). There are two groups of IPTs affecting adenine aromatic moiety found in Arabidopsis thaliana, including seven genes for ATP/ADP IPTs (IPT1, IPT3, IPT4, IPT5, IPT6, $I P T 7$, and IPT8) and two genes for transfer RNA IPTs (IPT2 and IPT9). Further research of various ipt mutants revealed that transfer RNA IPTs are responsible for biosynthesis of cis-zeatin- type CKs while ATP/ADP IPTs are involved in synthesis of isopentenyl adenine- and trans-zeatin- type CKs (Ha et al., 2012; O'Brien, Benkova, 2013). Moreover, relative interaction of $\mathrm{CK}$ with other phytohormones including abscisic acid and auxin, which are 
concerned as key phytohormones, has a critical role in plant development and adaptation (Růžička et al., 2009; Bishopp et al., 2011; Thu et al., 2017).

Although detailed understanding of molecular mechanism and pathways of CKs signaling is still limited, the great number of scientific evidence showed that CKs level adjustment and CK-encoding gene modulation would be a potentially powerful tool to enhance plant drought resistance. Normally, reducing $\mathrm{CK}$ concentration approaches by overexpressing a specific $C K X$ gene in root will induce root development and biomass accumulation without shoot retardation (Ha et al., 2012). However, there were reports on enhancement of IPT expression that could reduce root growth but still significantly contributes to drought resilience through reducing leaf senescence, free radical oxidation, and improving photosynthetic intensity (Rivero et al., 2010; Merewitz et al., 2011). Recent evidence demonstrated that over-expressing Agrobacterium tumefaciens IPT in cassava could increase drought tolerance and delay senescence in the transgenic plants (Zhang et al., 2010). Likewise, overexpressing the bacterial gene in peanut demonstrated significantly improved performance in photosynthetic rate, stomatal conductance and transpiration compared to the wild-type plants under water deficit (Qin et al., 2011). In another report, rice (Oryza sativa) over-expressing the ITP gene also exhibited enhanced grain yield quality and improved drought tolerance (Peleg et al., 2011).

IPT genes in soybean (GmIPTs) have been isolated and under functional characterization. In 2012, Le et al., analyzed their expression under normal and water stress conditions. According to their findings, among the studied GmIPTs, GmIPT08 transcripts were found to consistently increase in the leaves and shoots of young soybean seedling under dehydration conditions. The data also showed high transcriptional expression activity of another gene, GmIPT10, in roots and root hairs under drought stress condition. Taken together, these findings suggest that GmIPT8 and GmIPT10 are likely to involve in drought responses in soybean and thus could be employed to improve drought tolerance by genetic engineering approach.

To study the function of GmIPT10, different transgenic lines with RD29A-inducible promoter were generated at the University of Missouri (USA) using the Agrobacterium-mediated transformation method. In this study, we endeavored to analyze a number of main physiological characteristics involved in plant response to water deficit of a GmIPT10-over-expressing line and compared its performance with the non-transgenic soybean counterparts.

\section{MATERIALS AND METHODS}

\section{Growing conditions}

The plants were grown in net house condition with temperature range of $27-34^{\circ} \mathrm{C}$, humidity of 60 $70 \%$, natural photoperiod.

\section{Selection of homologous transgenic soybean carrying GmIPT10}

The seeds of transgenic (carrying RD29A::GmIPT10 and selective marker bar gene), positive control (carrying bar gene) generated by University of Missouri (USA) and wild-type (WT) (cultivar W82) soybean were germinated in trays and then transferred to net house with daily watering. To select the homozygous and single copied transgenic soybean line(s), the plants at V4 stage (22 days after germination) were sprayed with Basta (glufosinate ammonium) (80 mg/l, 3-ml dose per plant). Upon this treatment, the transgenics remained healthy and green while the non-transgenic plants displayed yellow, paled and/or wilted leaves. The screening for the line carrying homologous, singled copied transgene was performed based on Mendelian laws of inheritance and segregation.

\section{Shoot growth and root growth assay}

The method described in Thu et al. (2014) was adopted. In brief, the WT and homozygous transgenic plants carrying GmIPT10 were planted in plastic tubes (80-cm height, $10-\mathrm{cm}$ diameter) filled with Tribat soil (Saigon Xanh Bio-Technology Ltd Company, Vietnam). The 14-day-old plants were subjected to drought condition by withholding water for the next 16 days. Another set of plants for both genotypes remained watered for being used as controls. After the stress application period, the drought-treated and non-drought treated plants were removed gently out of the containers for recording lengths and fresh weights (FWs) of shoot and tap root of each individual plant. Next, these tissues were dried in oven at $65^{\circ} \mathrm{C}$ for 2 days before their dry weights (DWs) were measured. To evaluate the relative water content (RWC), additional step was performed between fresh weight and dry weight 
measurement, upon which the aerial part of each plant was soaked in water overnight then weighed to get the turgid weight (TW) (Ha et al., 2013). The $\mathrm{RWC}$ was determined using equation: $\mathrm{RWC}=(\mathrm{FW}$ - DW $) /($ TW - DW $) \times 100$.

\section{Plant drought tolerance evaluation}

Following the protocol described in Thu et al. (2014) with modification, 20-day drought treatment was applied to 14-day-old plants (grown in plastic tubes with $50 \mathrm{~cm}$ in height and $30 \mathrm{~cm}$ in diameter) by stopping watering, followed by water resumption. Control plants of both genotypes which were adequately watered were included. Soil moisture content (SMC) in each pot was monitored by using moisture meter (Total Meter, Taiwan), during the stress treatment, number of non-withered plants was recorded every 2 days.

\section{Statistical analyses}

The data were analyzed by Student's t-test (one tail, unpaired, equal variance) to identify the statistical significance with $p$-value $<0.05$.

\section{RESULTS AND DISCUSSION}

\section{Successful selection of homologous transgenic soybean carrying GmIPT10}

In this experiment, bar gene was used as an effective selectable marker for identification of the transgenic plants. This gene encodes phosphinothricin $\mathrm{N}$-acetyltransferase (PAT) enzyme, which confers resistance to Basta herbicide containing glufosinate ammonium (De Block et al., 1987; Song et al., 2013). Due to the large number of transgenic plants that were used for screening soybean events, Basta application was chosen as a quick, cheap but accurate method. After five days since Basta application, the whole leaves of the positive control plants (Fig. 1c) and transgenic plants possessing bar gene remained healthy and green (Fig. 1d). On the other hand, non-transgenic soybean and negative control were vulnerable and their leaves mostly turned yellow (Fig. 1a, b). Based on the Basta results and screening for several generations following Mendelian laws, we have identified one stable homozygous and single-copied line carrying GmIPT10 (line 175-27). Another notice was that development retardation was not observed in this line. Therefore, the line was used for subsequent experiments (Fig. 1d).
Transgenic plants had better root and shootrelated traits under normal condition

Shoot and root growth at vegetative stage (30 days of age) of WT and GmIPT10-over-expressing plants were examined under full irrigation condition. To ensure the plants were well watered, the soil moisture content (SMC) was regularly monitored. Following this, the SMC value was maintained within the range of $60 \sim 70 \%$ (Fig. 3a) throughout the experimental period, which was in agreement with other studies such as Thu et al., (2014). According to our record, although the transgenic and WT plants displayed similar average tap root length under normal condition (Fig. 3c), the transgenic plants had significantly higher trifoliate leaf number (Fig. 3g, p-value < $0.0001)$ and had higher average shoot length of $10.1 \mathrm{~cm}$ (Fig. 3d, $p$-value $<0.05$ ) than those of the WT, suggesting that the former might have a stronger photosynthesis performance and grain yield in normal condition (Qin et al., 2011).

It was also found out that there was a clear difference in biomass accumulation between the two examined genotypes. The transgenic plants had $40.8 \%$ higher mean of root and $28.22 \%$ higher mean of shoot dry matters ( $p$-values $<0.005$ ) compared to the corresponding parameters of the WT (Fig. 3e, f). In soybean, there is the strong linear relationship between mean dry matter and mean seed yield production (Mayers et al., 1991).

Taken all of these together, the transgenic plants displayed improved root and shoot traits compared to the WT counterpart in terms of number of trifoliate leaves, shoot length, and root and shoot dry matters. These obtained data indicate that the transgenic line is likely to have capacity in producing greater seed yield under field condition.

Transgenic plants had better root- and shootrelated traits under drought condition

To evaluate the drought tolerance, we ceased to water both WT and GmIPT10-over-expressing transgenic plants after 14 days growing them under normal condition, when both genotypes showed similar size. At the end of the drought period, the $\mathrm{SMC}$ in the containers of treated plants dropped substantially to around $30 \%$ (Fig. $3 \mathrm{~b}$ ). At this stage, the drought-treated transgenic plants were visibly much larger and stayed greener than the WT plants (Fig. 2). This clear observation was also found in transgenic cassava carrying Agrobacterium IPT upon 
drought treatment, which could be explained by delay of leaf senescence and relatively higher chlorophyll content compared with the WT (Zhang et al., 2010).

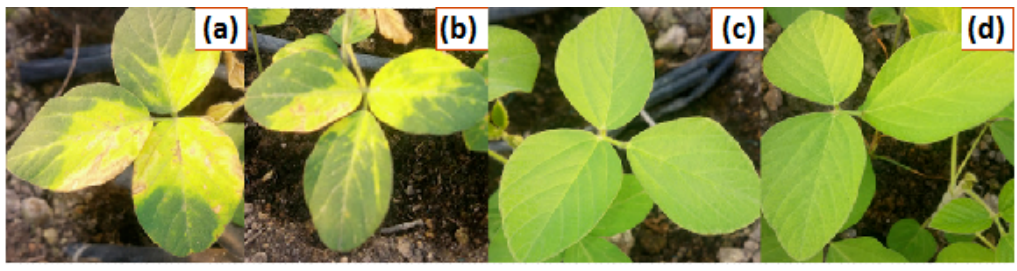

Figure 1. Identification of the transgenic soybean plants based on Basta resistance phenotype. Each plant was sprayed with 3-ml Basta solution at concentration of $80 \mathrm{mg} / \mathrm{l}$ (a) Negative control; (b) Sensitive plant; (c) Positive control; (d) Transgenic plant.

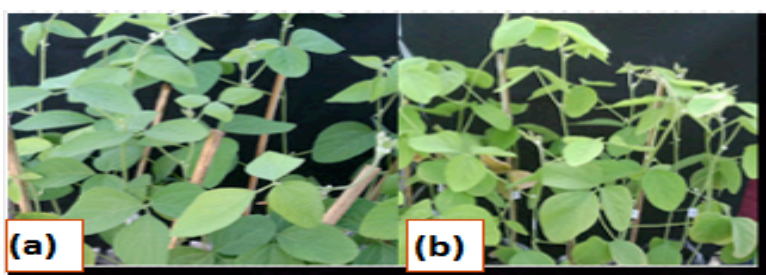

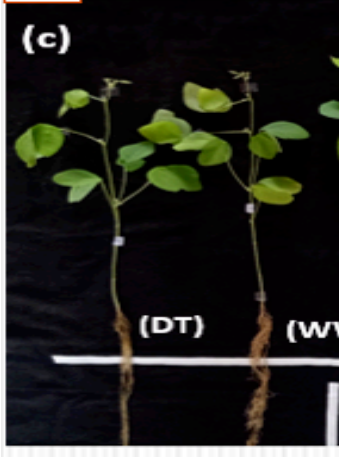

WT

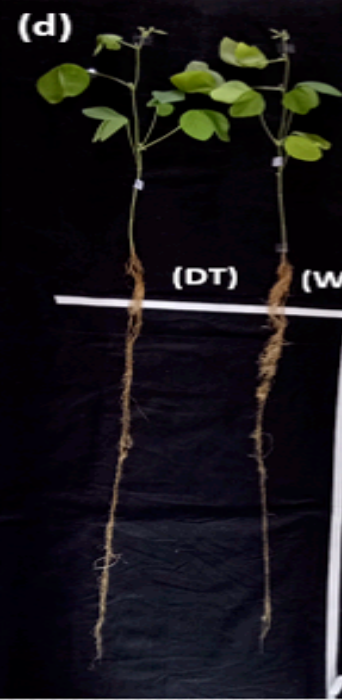

WT

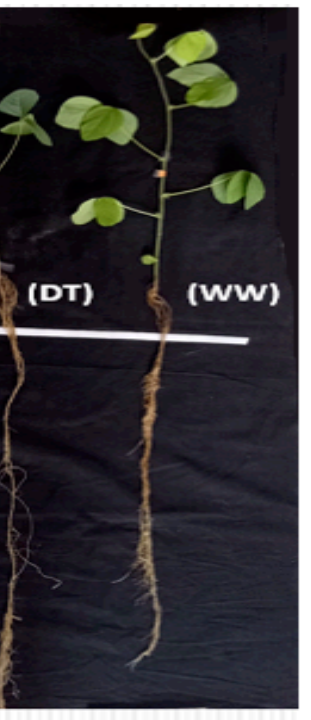

IPT10

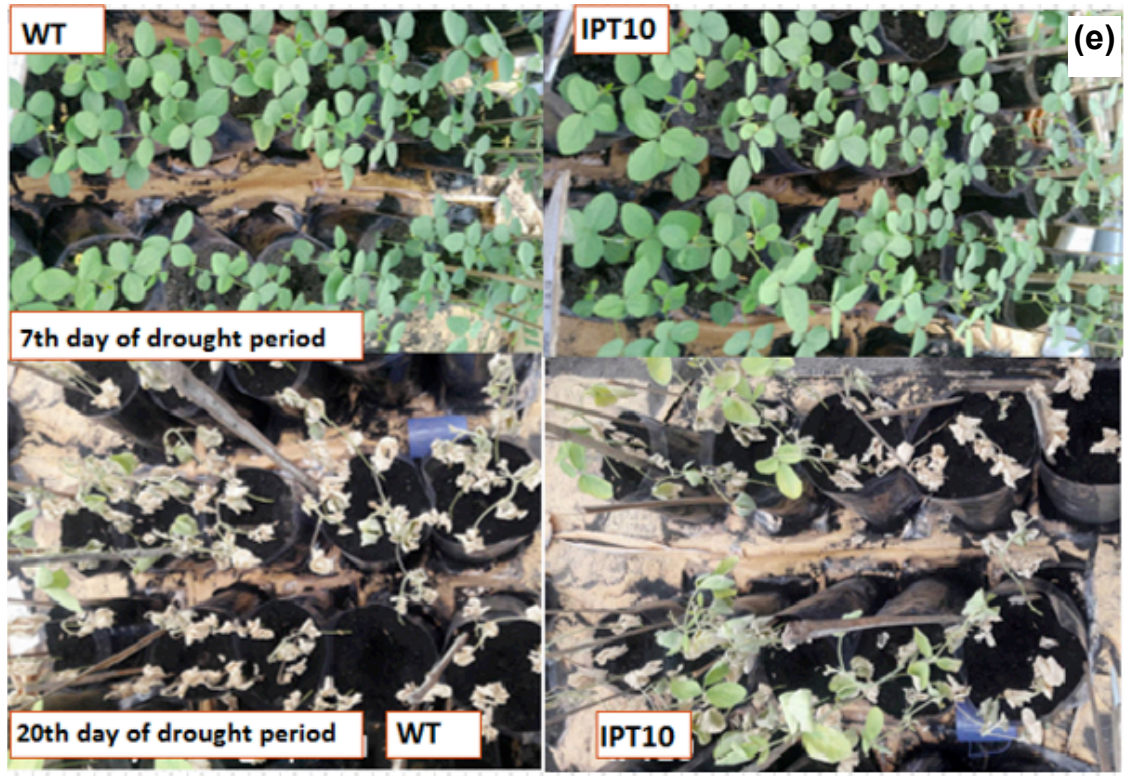

Figure 2. Phenotypes of GmIPT10-over-

expressing and wild-type soybean plants exposed to16-day drought treatment. (a) General display of transgenic plants upon drought stress; (b) General display of WT plants upon drought stress; (c) Shoot phenotypes of transgenic and WT plants; (d) Root phenotypes of transgenic and WT plants. WT: wildtype; IPT10: transgenic plant; DT: drought stress; WW: well-watered. (e) Phenotypic comparison of the two genotypes at 7-day (upper images) and 20-day drought treatment (below images) 

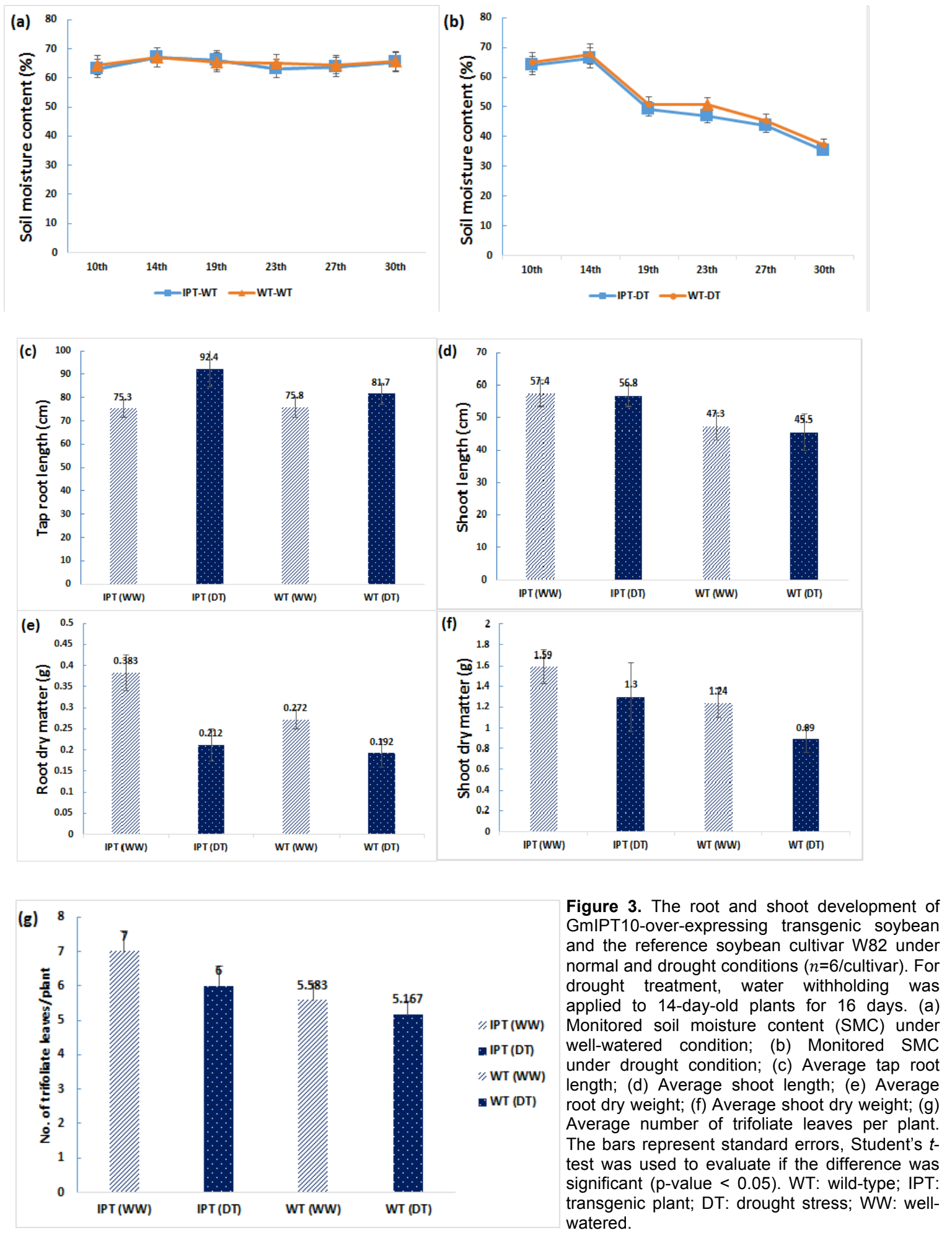

Under drought treatment condition, analyzing root trait revealed that the average tap root length of the GmIPT10-over-expressing line $(92.4 \mathrm{~cm})$ was significantly greater than that of the WT $(81.7 \mathrm{~cm})$ 
( $p$-value < 0.05) (Fig. 3c). With similar trend, the drought-treated transgenic plants had considerably longer shoot than that of the WT counterparts (56.8 $\mathrm{cm}$ and $45.5 \mathrm{~cm}$, respectively, $p$-value $<0.05$ ) (Fig. $3 \mathrm{~d})$. These results provide a good comparison between the transgenic and WT plants, as the former also displayed increased shoot dry weight ( $p$-value $<$ $0.01)$ and trifoliate leaf number $(p$-value $<0.0001)$ compared to those of WT soybean (Fig. 3f, g). Higher biomass accumulation in soybean transgenic plant under water deficit could be induced by higher photosynthetic rates, higher stomatal conductance and higher transpiration and improved water use efficiency since these improved biochemical parameters were found in peanut over-expressing IPT gene (Qin et al., 2011).

When evaluate the effect of drought to each genotype, the water shortage led to a significant reduction in shoot dry weight of the WT ( $p$-value $<$ 0.03 , Fig. 3f). Meanwhile, tap root of the transgenic plants under water deficit tended to be statistically much longer $(92.4 \mathrm{~cm})$ than the mean root length of the transgenic plants grown under well watering condition $(75.3 \mathrm{~cm})$ ( $p$-value $<0.001$, Fig. $3 \mathrm{c})$, although the drought stress still caused a substantial reduction in root dry matter ( $p$-value $<0.001$, Fig. $3 e)$. The observation in transgenic plant with strong development of primary root and reduction of lateral root was a good accordance with the criteria specified for genotype with improved phenotypic traits and better drought tolerance under drought stress (Thu et al., 2014). Promotion of primary root growth is to increase the probability of accessing water at deeper soil layer when water becomes limited while lateral root (LR) development is concerned as an adaptive adjustment to nutrient deficiency (Linkohr et al., 2002; Zhan et al., 2015). Exogenous CK was known as inhibitor of LR development (Li et al., 2006; Laplaze et al., 2007). It was reported that CKs inhibit LR development via regulating abscisic acid insensitive4 (ABI4), which encodes an ABA-regulated AP2 domain transcription factor in Arabidopsis, causing a reducing of polar auxin transport to promote LR formation (Shkolnik-Inbar, Bar-Zvi, 2010). Therefore, it is generally postulated that extending primary root length under water deficit seen in the studied GmIPT10-carrying transgenic plants might be due to CKs adjustment.

Taken together, our results indicated that the GmIPT10-over-expressing soybean line displayed improved drought tolerant traits, which are consistent with the results reported previously in studies by Oneto et al., (2016) in maize, Kuppu et al., (2013) in cotton and Qin et al., (2011) in peanut.

\section{Transgenic plants had lower penalty in RWC reduction upon drought stress exposure}

Relative water content was considered as one of the main parameters to evaluate the drought tolerance capacity in plants (Yan et al., 2016). The RWC reflects the plant ability to store water and minimizing cellular water loss due to drought effects will bring advantage for the plant to survive as well as to maintain its growth and development. The analyzed results indicated that under the same growing condition of drought application, the aerial parts of the transgenic and non-transgenic plants shared similar RWC values although the value of the former was slightly higher (Fig. 4b). However, the WT plants had a noteworthy penalty in RWC upon drought exposure (decreased by $6.37 \%, p$-value < 0.001 ) in comparison with its counterpart. For the transgenic plants, there were no significant difference in RWC values between the plants grown under normal and drought conditions. The results suggest that the transgenic line may have advantages in tolerance to drought stress.

\section{Transgenic plants had higher survival rate upon drought exposure}

Soybean plants were first grown in a net house with normal irrigation for 2 weeks, and then nonirrigation was applied in the next 20 days in order to evaluate the drought effect on the plant survival. According to our record, there were no phenotypic differences between the two genotypes, or between the drought treated and non-drought-treated plants within the early stage of drought stress exposure. However, after 18 days of water deficit, wilting symptoms were clearly seen. At this time-point, interestingly, the transgenic plants possessed higher survival percentage compared to the survival rate of the drought-treated WT $(97 \%$ versus $80 \%$, respectively, Fig. 5a). At the end of the drought treatment, $80 \%$ of the transgenic plants were still alive while the survival rate of the WT decreased to $50 \%$ (Fig. 5). Statistical comparison analyses showed that the transgenic line displayed significantly improved water-deficit tolerance in green house conditions ( $p$-value $<0.002)$. 

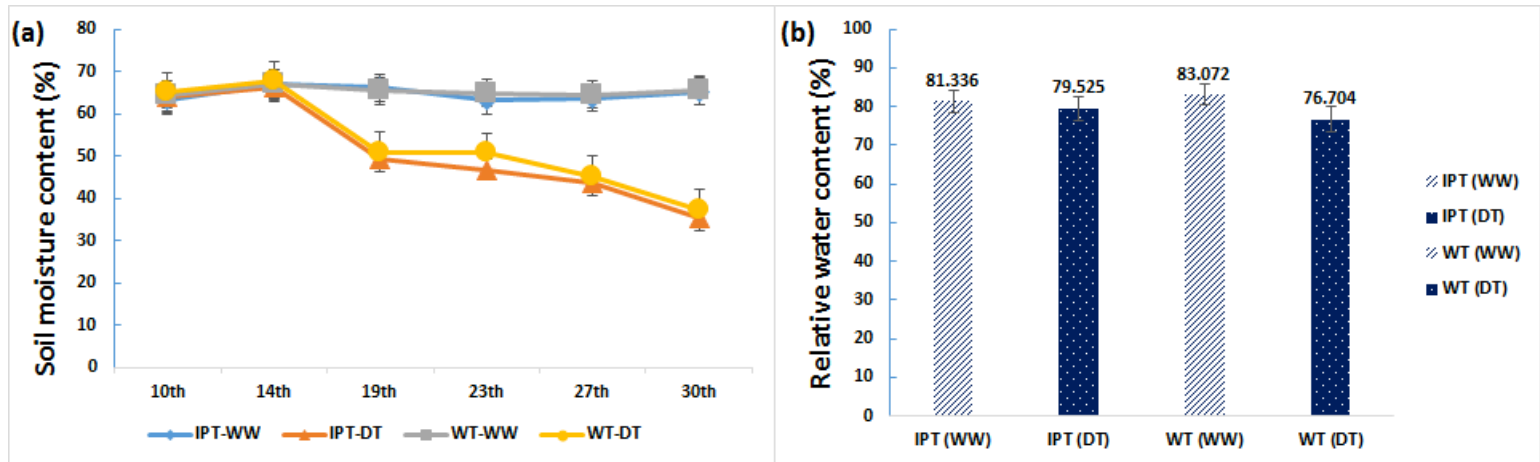

Figure 4. Examination of relative water content (RWC) of aerial part of GmIPT10-over-expressing and wild-type soybean plants. Sixteen-day drought period was applied, started when plants were 14 days old. (a) The SMC was monitored during the experiment $(n=10)$; (b) RWC values ( $n=10 /$ cultivar).
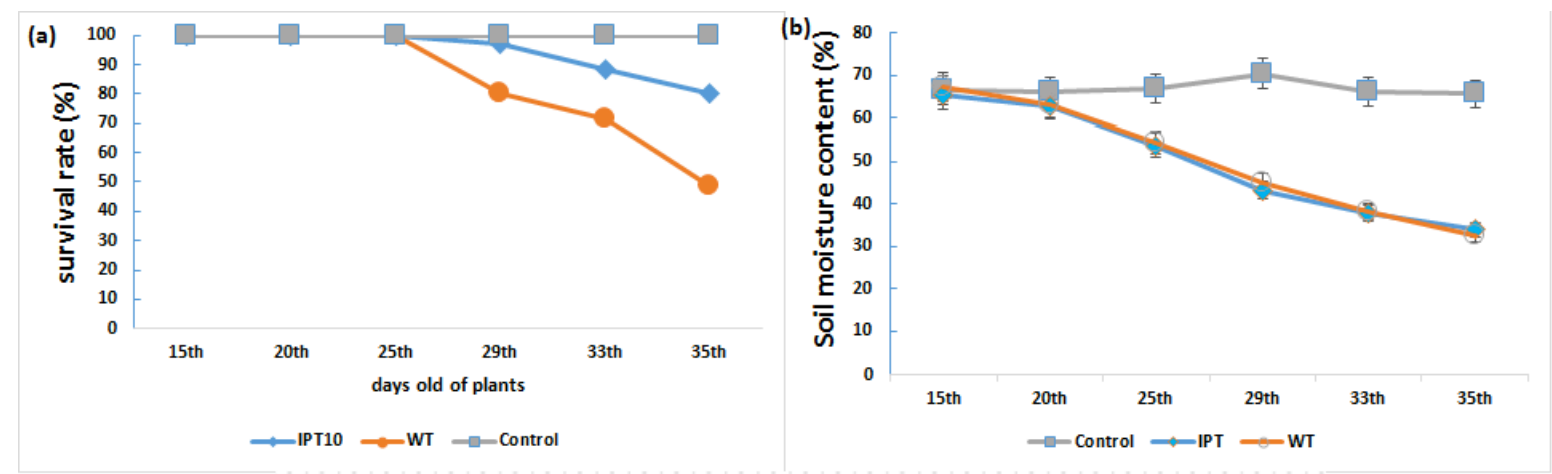

Figure 5. Evaluation of drought tolerance capacity of the GmIPT10-overexpressing and wild-type plants ( $n=35$ per genotype). The non-irrigation was applied for 20 days after growing the plants for 14 days under normal condition; (a) Survival rates of the two genotypes upon drought treatment; (b) Monitored soil moisture content during the experiment $(n=10)$; The bars indicate standard errors.

\section{CONCLUSION}

This study was the first example demonstrating that over-expression of GmIPT10 in soybean plants could improve root and shoot - related traits which would bring advantages for plants to cope with drought stress, including increased primary root and shoot lengths, better production of shoot biomass, higher number of trifoliate leaves, and higher survival rate than the non-transgenic plants under the stress condition. The obtained results indicate this transgenic line might have better drought tolerance capacity, and thus worthwhile to perform in-depth studies to precisely evaluate its tolerance ability to drought and its potential of economic application, as well as to get understanding of modulating mechanisms mediated by GIPTI0.
Acknowledgements: This research is funded by Vietnam National University Ho Chi Minh City (VNU-HCM) under grant number B2017-28-02.

\section{REFERENCES}

Aloni R, Aloni E, Langhans M, Ullrich CI (2006) Role of cytokinin and auxin in shaping root architecture: regulating vascular differentiation, lateral root initiation, root apical dominance and root gravitropism. Ann Bot 97: 883-893.

Bishopp A, Help H, El-Showk H, Weijers D, Scheres B, Friml J, Benková E, Mähönen AP (2011) A mutually inhibitory interaction between auxin and cytokinin specifies vascular pattern in roots. Curr Biol 21: 917-926.

De Block M, Bottleman J, Vandewiele M, Dockx J, Thoen C, Gosselé V, Movva NR, Thompson C, Montagu MV, Leemans J (1987) Engineering herbicide resistance in 
plants by expression of a detoxifying enzyme. $E M B O J 6$ : 2513-2518.

Guttikonda SK, Valliyodan B, Neelakandan AK, Tran LS, Kumar R, Quach TN, Voothuluru P, Gutierrez-Gonzalez JJ, Aldrich DL, Pallardy SG, Sharp RE, Ho TH, Nguyen HT (2014) Overexpression of AtDREBID transcription factor improves drought tolerance in soybean. Mol Biol Rep 41: 7995-8008.

Ha S, Vankova R, Yamaguchi-Shinozaki K, Shinozaki K, Tran LS (2012) Cytokinins: metabolism and function in plant adaptation to environmental stresses. Trends Plant Sci 17: 172-179.

Ha CV, Le DT, Nishiyama R, Watanabe Y, Tran UT, Dong NV, Tran LSP (2013) Characterization of the newly developed soybean cultivar DT2008 in relation to the model variety W82 reveals a new genetic resource for comparative and functional genomics for improved drought tolerance. Biomed Res Int 2013:1-8.

Hwang I, Sheen J (2001) Two-component circuitry in Arabidopsis cytokinin signal transduction. Nature 413: 383-389.

Inoue T, Higuchi M, Hashimoto Y, Seki M, Kobayashi M, Kato T, Tabata S, Shinozaki K, Kakimoto T (2001) Identification of CRE1 as a cytokinin receptor from Arabidopsis. Nature 409: 1060-1063.

Kuppu S, Mishra N, Hu R, Sun L, Zhu X, Shen G, Blumwald E, Payton P, Zhang H (2013) Water-deficit inducible expression of a cytokinin biosynthetic gene IPT improves drought tolerance in cotton. PLoS One 8: e64190.

Laplaze L, Benkova E, Casimiro I, Maes L, Vanneste S, Swarup R, Weijers D, Calvo V, Parizot B, HerreraRodriguez MB, Offringa R, Graham N, Doumas P, Friml J, Bogusz D, Beeckman T, Bennett M (2007) Cytokinins act directly on lateral root founder cells to inhibit root initiation. Plant Cell 19: 3889-3900.

Le DT, Nishiyama R, Watanabe Y, Vankova R, Tanaka M, Seki M, Ham LH, Yamaguchi-Shinozaki K, Shinozaki K, Tran L-SP (2012) Identification and expression analysis of cytokinin metabolic genes in soybean under normal and drought conditions in relation to cytokinin levels. PLoS One 7: e42411.

Li X, Mo X, Shou H, Wu P (2006) Cytokinin-mediated cell cycling arrest of pericycle founder cells in lateral root initiation of Arabidopsis. Plant Cell Physiol 47: 11121123.

Linkohr BI, Williamson LC, Fitter AH, Leyser HM (2002) Nitrate and phosphate availability and distribution have different effects on root system architecture of Arabidopsis. Plant J 29: 751-760.

Mayers JD, Lawn RJ, Byth DE (1991) Adaptation of soybean (Glycine max (L.) Merrill) to the dry season of the tropics. I. Genotypic and environmental effects on phenology. Aust J Agric Res 42(3): 497-515.

Merewitz EB, Gianfagna T, Huang B (2011) Protein accumulation in leaves and roots associated with improved drought tolerance in creeping bentgrass expressing an ipt gene for cytokinin synthesis. J Exp Bot 62: 5311-5333.

Müller B, Sheen J (2007) Arabidopsis cytokinin signaling pathway. Sci STKE 2007: cm5.

Müller B, Sheen J (2008) Cytokinin and auxin interplay in root stem-cell specification during early embryogenesis. Nature 453: 1094-1097.

O'Brien JA, Benková E (2013) Cytokinin cross-talking during biotic and abiotic stress responses. Front Plant Sci 4: 451 .

Oneto CD, Otegui ME, Baroli I, Beznec A, Faccio P, Bossio, Blumward E, Lewi D (2016) Water deficit stress tolerance in maize conferred by expression of an isopentenyltransferase (IPT) gene driven by a stress-and maturation-induced promoter. J Biotechnol 220: 66-77.

Peleg Z, Reguera M, Tumimbang E, Walia H, Blumwald E (2011) Cytokinin-mediated source/sink modifications improve drought tolerance and increase grain yield in rice under water-stress. Plant Biotechnol 9: 747-758.

Qin H, Gu Q, Zhang J, Sun L, Kuppu S, Zhang Y, Burow M, Payton P, Blumward E, Zhang H (2011) Regulated expression of an isopentenyltransferase gene (IPT) in peanut significantly improves drought tolerance and increases yield under field conditions. Plant Cell Physiol 52: 1904-1914.

Rivero RM, Gimeno J, Van DA, Walia H, Blumwald E (2010) Enhanced cytokinin synthesis in tobacco plants expressing pSARK::IPT prevents the degradation of photosynthetic protein complexes during drought. Plant Cell Physiol 51: 1929-1941.

Růžička K, Šimášková $M$, Duclercq J, Petrášek J, Zažímalová E, Simon S, Friml J, Montagu MCEV, Benková E (2009) Cytokinin regulates root meristem activity via modulation of the polar auxin transport. Proc Natl Acad Sci USA 106: 4284-4289.

Shkolnik-Inbar D, Bar-Zvi D (2010) ABI4 mediates abscisic acid and cytokinin inhibition of lateral root formation by reducing polar auxin transport in Arabidopsis. Plant Cell 22: 3560-3573.

Song ZY, Tian JL, Fu WZ, Li L, Lu LH, Zhou L, Shan ZH, Tang GX, Shou HX (2013) Screening Chinese soybean genotypes for Agrobacterium-mediated genetic transformation suitability. J Zhejiang Univ Sci B 14: 289-298.

Thao NP, Tran LSP (2012) Potentials toward genetic engineering of drought-tolerant soybean. Crit Rev Biotechnol 32: 349-362. 
Thu NBA, Hoang XLT, Truc MT, Sulieman S, Thao NP, Tran LSP (2017) Cytokinin signaling in plant response to abiotic stresses. In: Pandey G (ed.), Mechanism of Plant Hormone Signaling under Stress. John Wiley \& Sons.

Thu NBA, Nguyen QT, Hoang XLT, Thao NP, Tra, LSP (2014) Evaluation of drought tolerance of the Vietnamese soybean cultivars provides potential resources for soybean production and genetic engineering. Biomed Res Int, 2014:1-9.

Tran LSP, Mochida K (2010) Functional genomics of soybean for improvement of productivity in adverse conditions. Funct Integr Genomics 10: 447-462.

Werner T, Nehnevajova E, Köllmer, Novák O, Strnad M, Krämer U, Schmülling T (2010) Root-specific reduction of cytokinin causes enhanced root growth, drought tolerance, and leaf mineral enrichment in Arabidopsis and tobacco. Plant Cell 22: 3905-3920.

Yan W, Zhong Y, Shangguan Z (2016) A meta-analysis of leaf gas exchange and water status responses to drought. Sci Reports 6: 20917.

Zhan A, Schneider H, Lynch JP (2015) Reduced lateral root branching density improves drought tolerance in maize. Plant Physiol 168: 1603-1615.

Zhang P, Wang WQ, Zhang GL, Kaminek M, Dobrev P, $\mathrm{Xu}$ J, Gruissem W (2010) Senescence-inducible expression of isopentenyl transferase extends leaf life, increases drought stress resistance and alters cytokinin metabolism in cassava. J Integr Plant Biol 52: 653-669.

\title{
PHÂN TÍCH MộT SỐ TÍNH TRẠNG SINH LÝ CỦA CÂY CHUYỄN GEN TĂNG CƯờNG BIỂU HIỆN GmIPT10 Ở ĐIỂU KIỆN TRỒNG BÌNH THƯờNG VÀ CÓ XỬ LÝ STRESS HẠN
}

\author{
Nguyễn Ngọc Hải, Nguyễn Đức Văn Thiện, Hoàng Thị Lan Xuân, Nguyễn Phương Thảo \\ Trường Đại học Quốc tế, Đại học Quốc gia Thành phố Hồ Chi Minh
}

\section{TÓM TẮT}

Cytokinin $(\mathrm{CKs})$ là một loại hormone thực vật có vai trò quan trọng không chỉ trong quá trình phát triển mà còn trong quá trình chống chịu stress ở cây trồng. Các nghiên cứu trước cho thấy việc nâng cao khả năng chống hạn của cây bằng cách dùng kích thích stress để tăng cường biểu hiện của gen mã hóa enzyme adenine isopentenyl transferase (IPT) liên quan đến tổng hợp $\mathrm{CK}$, là một trong những giải pháp khả thi. Để nghiên cứu vai trò của GmIPT10 ở đậu tương trong giúp cây chống hạn, chúng tôi đã tạo được cây chuyển gen có biểu hiện vượt mức GmIPT10 và sàng lọc thành công dòng đậu tương mang một bản sao của gen chuyển GmIPT10 ở dạng đồng hợp. Đánh giá các tính trạng sinh lý cho thấy so với cây không chuyển gen đối chứng, dòng cây chuyển gen mang nhiều tính trạng liên quan đến khả năng chống chịu hạn bao gồm tăng cường chiều dài rễ chính và thân, tăng khối lượng sinh khối, có số lá kép ba lá nhiều hơn và có tỉ lệ sống sót cao hơn khi được thử nghiệm stress hạn. Kết quả thực nghiệm trong nhà lưới cũng cho thấy dòng chuyển gen GmIPT10 có chỉ số hàm lượng nước tương đối trong mô chồi cao hơn dưới điều kiện stress. Những kết quả này cho thấy việc nâng cao khả năng chịu hạn của cây có thể thực hiện được thông qua điều phối sự biểu hiện của GmIPT10.

Từ khóa: Cây chuyển gen, chống chịu hạn, Cytokinin, đậu tuoong, GmIPT10 